\title{
Panel Data Analysis on Corporate Effective Tax Rates of Some Listed Large Firms in Nigeria
}

\author{
Samuel Olorunfemi Adams ${ }^{1 *}$, Philomena Omoshade Balogun ${ }^{2}$
}

\author{
${ }^{1}$ Department of Statistics, University of Abuja, FCT, NIGERIA \\ ${ }^{2}$ Department of Statistics, Federal Polytechnic Bida, Niger State, NIGERIA \\ *Corresponding Author: samuel.adams@uniabuja.edu.ng
}

Citation: Adams, S. O. (2020). Panel Data Analysis on Corporate Effective Tax Rates of Some Listed Large Firms in Nigeria. Dutch Journal of Finance and Management, 4(2), em0068. https://doi.org/10.21601/djfm/9345

ARTICLE INFO

Received: 30 Aug. 2020

Accepted: 11 Oct. 2020

\begin{abstract}
Corporate effective tax rates (ETR) of large Nigerian listed firms during the new tax regime as well as the influence of firm size, leverage, return on asset, capital intensity, and inventory intensity on corporate effective tax rate was investigated. The study aims to examine the influence of some corporate tax attributes in some selected large public listed firms within and across Nigeria with avoidance of corporate effective tax rates (ETR). The data used in the study was extracted from the 2019 Nigeria Annual Financial reports. The data were collected from the period 2012 to 2018, the period where Nigeria imposed a new tax regime on the current year assessment system (effective from the year 2012). Pooled ordinary least square (POLS), fixed effect and random effect regression were applied to the data, findings from the study revealed that the random effect regression model was preferred for result interpretation. It was also discovered that; firm size (FSIZE), return on assets (ROA), and inventory intensity (INVINT) have a positive and significant influence on corporate effective tax rates (ETR) avoidance. Firm leverage (LEV) and capital intensity (CAPINT) on the other hand has an insignificant inverse influence on effective tax rates (ETR). Hence, this study suggested that firm size (FSIZE), return on assets (ROA), and inventory intensity (INVINT) is the major variable that positively influences the corporate effective tax rates (ETR) the listed large firms in Nigeria.
\end{abstract}

Keywords: effective tax rates, return on asset, firm leverage, firm size, capital intensity, inventory intensity

\section{INTRODUCTION}

Tax is a compulsory payment of money to the Government by an Individuals or Organizations as the Government covers its expenses on various public functions, and its interference in political, economic, and social life without direct return of benefit to be derived by the taxpayer. In other words, there is no direct return to the taxpayer for what he pays, though the public in general derives a common benefit. Thus, tax is a mandatory distribution collected by the Government to meet the expenses of various public functions. The principle of taxation should be to impose the least sacrifice on the people as a whole, even if it means imposing more sacrifice on some people and less on others. It is not a price paid by the taxpayer for any definite service by the Government. Modern Government, being a welfare Government, should try to minimize the sacrifice of the community. Taxes policy has been an important instrument for augmenting revenue, where it is the major source of domestic revenue. It is also an important instrument for attaining a proper pattern of resource allocation, distribution of income and wealth, reduction of poverty among people, and economic stability, in order that the benefits of economic development are evenly distributed.

Taxation has rightly been identified as a major tool in the strengthening of domestic resource mobilization and consequently, the search for ways and means of expanding the tax base and also strengthening effective tax rate has been intensified. That taxation has been one of the most important weapon available to the government for marshaling financial resources is undisputable (Atta-Mills, 2002; Oloyede, 2010; Teidi, 2003). Governments impose many types of taxes in most developed countries, individuals pay income taxes when they earn money, consumption taxes when they spend it, property taxes when they own a home or land, and in some cases estate taxes when they die. In the United States, federal, state, and local governments all collect taxes. Taxes on people's income play critical roles in the revenue systems of all developed countries.

From the foregoing, non-oil revenue especially tax has been the mainstay of most developed countries, in contrast to developing countries that still depend on primary products. Also, indirect taxes appear to be in vogue in developed countries, due to higher return, lower administration cost and 
higher compliance rate; however, most developing countries still rely on direct taxes with lower compliance rate (Oloyede, 2010).

The Nigerian tax system has undergone several reforms geared towards enhancing tax collection and administration with minimal enforcement costs. The recent reforms include the introduction of TIN (Tax Payers Identification Number), which became effective since February 2008. Automated Tax System (ATS) that facilitates tracking of tax positions and issues by the individual taxpayer, E-Payment System (EPS) which enhances smooth payment procedure and reduces the incidence of tax touts, Enforcement scheme (special purpose tax officers), all these have led to an improvement in the tax administration in the country. In the face of unbeaten debt difficulties, coupled with domestic and external financial imbalances confronting them, it is not surprising that many developing nations have been forced to adopt stabilization and adjustment policies which demand better and more efficient methods of mobilizing domestic financial resources with a view to achieving financial stability and promoting economic growth. According to Surrey (Atta-Mills, 2002), it is increasingly apparent, however, that tax administration must receive far greater attention if the goals of tax policy are to be attained. Much of the tax policy is being directed to obtaining increased revenues to enable governments to carry out their economic planning.

It is true in Nigeria that the successful administration of some of the existing taxes would provide a considerable part of the needed additional revenue. The feature and problematic aspect of Nigeria's tax system is the location of the assessment and collection functions within the tax system. Problems also emanate from the frequent changes in the tax laws: Every year the annual budget estimate introduces new measures and procedures, amends or cancels existing ones (new tax regime). These frequent changes can make the law confusing as well as complicate the tax structure. After a few years, these changes and amendments become so many that the taxpayer finds it difficult to know which laws are applicable. There is the need, therefore, for the tax administration to undertake periodic codification of the tax laws so that it can have all the amendments and changes compiled into one statue to which both have easy and ready access. Another institutional arrangement that seems to impede the efficiency and effectiveness of the tax rate in Nigeria is the linkage of the revenue administration with the civil service. The revenue administration, therefore, reflects the weaknesses and structural defects existing within the civil service organization, especially executive bureaucracy, low morale, and inadequate resources. Other problems include; noncompliance strategy, multiple taxes, absence of Equity in Tax Administration, lack of motivation, and remuneration. It is important to consider the possible explanatory variables for the ETR borne by companies because most business decisions have fiscal repercussions. Conversely, the tax burden should be considered when companies make business decisions. Companies should be aware that their ETRs are affected by their previous investment and funding decisions. This study aimed to examine the influence of some corporate tax attributes in some selected large public listed firms in Nigeria with the avoidance of corporate effective tax rates (ETR). This paper is organized into five sections. In Section "Literature Review", the literature review on corporate effective tax rate was presented. In Section "Materials and Methods", materials and methods used for modeling are outlined. In Section "Results and Discussions", the results and discussions for the study are presented, while conclusions are presented in the last section.

\section{LITERATURE REVIEW}

Most of the previous ETRs studies were based on a simple pooled cross-sectional or time series models. However, Gupta and Newberry (1997), and Feeny et al. (2002) used fixed effects and random effects models to determine the relationship between corporate ETRs and their characteristics, and the results indicated that these models provide better specification estimates. The fixed effects and random effects specifications consider both companies' observed and unobserved heterogeneity in the multivariate regression model. Further, these models consider the possible non-linear relationship between ETR and its determinants, as well as, to control for the possible non-normal distribution of financial accounting data (Salaudeen, 2007). In a fixed-effects model, the data are assumed to be not randomly distributed and the unobserved company-specific characteristic is correlated with the included explanatory variables. Therefore, a fixed-effects model accounts for individual company heterogeneity via company-specific constants in the model which capture the effects of unmeasured company characteristics that vary by company, but relatively stable over time for a given company Gupta and Newberry (1997), and Feeny et al. (2002). However, a fixed-effects model produces parameter estimates which are sample-specific; so inferences are not generalized outside the sample. On the other hand, a random-effects model accounts for individual-specific characteristics as a normallydistributed random variable and assumes that the individualspecific effects are uncorrelated with the regressors. In this model, the intercept $\beta_{0}$ represents the mean value of all the cross-sectional intercepts and the error component; it represents the random deviation of individual intercepts from the mean value. Whereas, in a fixed-effects model, each crosssectional unit has its own fixed intercept value (Gujarati, 2003). Therefore, this study uses a fixed-effects model, a random-effects model, and a pooled OLS model to estimate the coefficient for each of the explanatory variables, and the results are compared as robustness checks.

Firm size is the most widely used variable in the prior research on the corporate tax burden for two opposing reasons. The relationship will be positive under the political cost hypothesis, where the greater visibility of larger firms exposes them to greater regulatory actions. In contrast, the relationship will be negative if large firms have greater scope for tax planning or adopt accounting practices that lower their ETRs. Larger firms might also enjoy political power. The empirical evidence does not show a clear relationship between firm size and the ETR. Fernández-Rodríguez and MartínezArias (2014), Calvé Pérez et al. (2005), Noor et al. (2010), Omer et al. (1993), Plesko (2003), Wang (1991), and Zimmerman (1983) show a positive relationship between firm size and tax 
burden, in line with the political cost hypothesis. Conversely, Chen Chen et al. (2010), Derashid and Zhang (2003), Harris and Feeny (1999), Janssen (2005), Kim and Limpaphayom (1998), Porcano (1986), and Richardson and Lanis (2007) show a negative relationship, maintaining that firm size may be inversely related to the tax burden. However, Gupta and Newberry (1997), Fernández-Rodríguez and Martínez-Arias (2014), Zimmerman (1983), Feeny et al. (2006), FernándezRodríguez (2004), Liu and Cao (2007), Stickney and McGee (1982) and Wilkinson et al. (2001) do not show any significant relationship between firm size and ETR.

The relationship between corporate capital structure and tax avoidance has been extensively studied in the literature, both theoretically and empirically. The deductibility in CIT of interest payments on debt reduces the cost of financing with debt in comparison with other alternatives FernándezRodríguez and Martínez-Arias (2014) and Badarau-Semenescu and Semenescu (2010). This option may make leverage preferable to equity because, in most countries, equity does not enjoy a tax incentive in CIT. According to this traditional approach, Modigliani and Miller (1963) maintain that the tax savings that result from business leverage mean that the value of the firm depends not only on the value of investment opportunities but also on any financing decisions taken. In fact, they state that only when the existence of CIT is considered does the value of the leveraged firm equal that of the unleveraged firm plus the value of the debt tax shield (Fernández-Rodríguez and Martínez-Arias, 2014). The relationship between leverage and tax burden has been tested empirically in studies such as those by Calvé Pérez et al. (2005), Noor et al. (2010), Plesko (2003), Richardson and Lanis (2007), Fernández-Rodríguez (2004), Liu and Cao (2007), and Stickney and McGee (1982), which find a negative relationship between leverage and tax burden in line with this traditional approach. Alternatively, it is possible to find a positive relationship between ETR and leverage to the extent that firms may be motivated to take on debt in order to reduce their ETRs. Chen Chen et al. (2010), Harris and Feeny (1999), Janssen (2005), and Feeny et al. (2006), find this positive relationship. However, Kim and Limpaphayom (1998) and Wilkinson et al. (2001) do not find any significant relationship between leverage and ETR. Finally, Fernández-Rodríguez and Martínez-Arias (2011) find a nonlinear relationship between leverage and ETR; it is positive up to a certain level, after which it becomes negative.

Fernández-Rodríguez and Martínez-Arias (2011) find a nonlinear relationship between capital intensity and tax burden, it is positive up to a certain level of noncurrent assets and negative thereafter. When considering the relation between ETR and assets, we should remember that the sector of activity clearly determines the asset mix, so the possibility of obtaining lower ETRs will depend on the volume of current assets that firms need for their activity and, more specifically, on their inventory level. From this perspective, investment in inventories is considered an alternative to using funds for tangible fixed assets, so it limits the possibility of reducing the ETR (Fernández-Rodríguez and Martínez-Arias, 2014). Inventory intensity could therefore be considered to lead to a larger tax burden. Inventory level as an explanatory variable for ETR is not widely used in prior research. Only Gupta and Newberry (1997), Richardson and Lanis (2007) and Fernández-
Rodríguez (2004) use it, finding a statistically significant relation. Derashid and Zhang (2003), and Adhikari et al. (2006) also analyze inventories but without finding any statistically significant relationship (Fernández-Rodríguez and MartínezArias, 2014). From the perspective of the asset mix and considering all the above arguments, and in line with most previous studies, a positive relationship can be expected between ETR and inventory intensity.

\section{MATERIALS AND METHODS}

\section{Source of Data}

The data used in this study are collected from the 2019 Nigeria Annual Financial reports. The data are collected from the period 2012 to 2018, the period where Nigeria imposed a new tax regime on the current year assessment system (effective from the year 2012). The sample consists of companies from sectors listed, which includes industrial products, trading, and services, consumer products, properties, plantation, construction, technology, infrastructure, hotel, and mining sectors. Companies with non-industrial templates are removed. These include banks, insurance companies, trust, and other financial companies. Further, to create the 2012-2018's panel data, companies must have non-missing financial information for all the five years of the investigation periods. The short length of the panel reduces the chance of survivorship bias affecting the results (Feeny et al., 2002). Thus, the exclusion of companies with insufficient data resulted in a panel data of 319 companies over the period 2012 - 2018 (2233 firm-years) used in this study.

\section{Model Specification}

The empirical analysis in this study uses the following general multivariate model.

$$
\begin{gathered}
\text { ETR }_{t}=\beta_{0}+\beta_{1} \text { SIZE }_{t}+\beta_{2} \text { LEV }_{t}+\beta_{3} \text { CAPINT }_{t}+ \\
\beta_{4} \text { ROA }_{t}+\beta_{5} I N V I N T_{t}+\epsilon_{i}
\end{gathered}
$$

Where; ETR is the total tax expense (current income tax expense plus deferred tax expense) divided by income before interest and taxes; $\beta_{0}$ is the constant; $\beta_{1}$ SIZE is a firm size measured as log of total assets; $\beta_{2}$ LEV is firm leverage measured as long term debts divided by total assets; $\beta_{3}$ CAPINT is capital intensity measured as fixed assets divided by total assets; $\beta_{4} \mathrm{ROA}$ is the return on assets measured as pre-tax income divided by total assets; $\beta_{5}$ INVINT is inventory intensity measured as inventory divided by total assets, $\epsilon_{i}$ is an Error term; $t$ is the firm-years between 2012 to 2018 .

\section{Panel Data Estimation Procedures}

Panel regression analysis is a regression that involves the combination of time series and cross-sectional data: panel data. It is repeated observation on the same cross-section, type of individual variables that are observed for several time periods (Pesaran et al., 2000; Wooldridge, 2010). Panel data is an important method of longitudinal data analysis because it allows for a number of regression analyses in both spatial (units) and temporal (time) dimensions. The spatial aspect refers to a number of cross-sectional units of observation, which could be countries, states, firms (as used in this study), 
commodities, and so on while the temporal aspect refers to regular episodic observations of a set of variables in the crosssection units over a particular period of time (i.e. 2012 - 2018). Panel data also provides a major means to analyze data longitudinally especially when the data are from various sources and the time series are rather short for separate time series analysis. Even in a situation when the observations are long enough for separate analyses, panel data analysis gives a number of techniques that can help examine changes over time common to a particular type of cross-sectional unit. A balanced panel data framework (i.e. when there are no missing values) as used in this study. Basically, a linear model for panel data enables the intercept and slope coefficients to vary over both the individual unit and over time, which is presented as follows;

$$
y_{i t}=\alpha_{i t}+\beta_{i t} X_{i t}+\mu_{i t}
$$

Where; $y_{i t}$ is a vector of the dependent variable, $\alpha_{i t}$ is a vector of constant parameter $\beta_{i t}$ is a vector of coefficients, $X_{i t}$ is a $\mathrm{K} \times 1$ vector of independent variables, $\mu_{i t}$ is a scalar disturbance term, $I$ represent the firm in a cross-section and $t$ represents time dimension.

\section{Pooled regression model}

The Pooled Regression Model is the simplest among the three models in panel data analysis. However, it disregards the space and the time dimensions of pooled data. In a situation where there is neither significant cross-section unit nor significant temporal effects, one could pool all the data and run an ordinary least square (OLS) regression model. Since there are situations where neither company (unit) nor temporal effects are statistically significant, equation (2) is restructured thus:

$$
y_{i t}=\alpha+\beta_{i t} X_{i t}+\mu_{i t}
$$

\section{Fixed effects model}

In fixed-effect models, the intercept in the regression model is allowed to vary across space (individual company) as a result of the fact that each cross-sectional unit may have some special characteristics. It is very suitable in cases where individual-specific intercepts may be correlated with one or more regressors (independent variables). In order to take into cognizance the different intercepts, the mean differencing or dummy method are usually employed based on which is found more suitable. Thus, equation (2) will then be based on the assumptions made on $\alpha$, $\beta i t$, and $\mu$ it i.e. the intercept, the slope coefficients, and the error term respectively. Under this method, some possibilities exist where each case introduces increasing complexity in estimating panel data models. Two of them are considered relevant for this study, which is as stated below:

(i) The slope coefficients, $\beta i t$, are constant but the intercept, $\alpha$ varies across space. Thus, equation (1) can be rewritten as: $\alpha_{i}$ is individual intercepts (fixed for given $\mathrm{N}$ ).

$$
Y_{i t}=\alpha+X_{i t}^{1} \beta+\mu_{i t} \text { ory }_{i t}=\sum_{j=1}^{N} \alpha_{j} d_{j i t}+\beta x_{i t}
$$

(ii) The slope coefficients are constant but the intercept varies across units $(i)$ and time $(t)$. Thus equation (2) can be rewritten as:

$$
\begin{gathered}
Y_{i t}=\alpha_{i}+y_{t} \beta_{i t}+\mu_{i t} \\
\text { or } \\
y_{i t}^{t}=\sum_{j=1}^{N} \alpha_{j} d_{j i t}+\sum_{s=2}^{T} y_{s} d_{s i t}+\beta x_{i t}+\mu_{i t}
\end{gathered}
$$

The number $N$ of individual dummies, $d_{j i t}$ equal one if $i=$ $j$ and equal zero otherwise, while the time dummies $(T-1)$, $d s$.it equal one if $t=s$ and zero otherwise. It is equally assumed that $x_{i t}$ does not include an intercept. When an intercept is added there will be a loss of one degree of freedom, because one of the $N$ individual dummies would have to be dropped. This model has $N+(T-1)+\operatorname{dim}[X]$ parameters that can be consistently estimated if both $N \rightarrow \infty$ and $T \rightarrow \infty$. In short, panels where $N \rightarrow \infty$ but $T$ does not, the ys can be consistently estimated, so the ( $T$ - 1$)$ time dummies are simply incorporated into the regressors, $x_{i t}$ The problem thus lies in estimating the parameters, $\beta$ controlling for the $N$ individual intercepts, $\alpha i$. To resolve this problem, one can have dummies for groups of observations like industry.

\section{Random effect model}

The random effect model is an alternative to the fixedeffect model. The individual intercept is expressed as a deviation from this constant mean value. One major advantage of the random effect model over the fixed effect model is that it is economical in degrees of freedom. This is because there is no estimate of $N$ cross-sectional intercepts but just the mean value of the intercept and its variance. The random effect model is the best in cases where the (random) intercept of each cross-sectional unit is uncorrelated with the regressors. It is written mathematically as:

Random effects model, RE:

$$
Y_{i t}=\beta_{1 i}+\beta_{2 i} X_{2 i t}+\beta_{3 i} X_{3 i t}+\mu_{i t}
$$

Rather than assuming $\beta_{1 i}$ as fixed, it is taken that it is a random variable with a mean value of $\beta_{1}$. The intercept value for an individual cross-section unit (e.g. company) is then stated as:

$$
\beta_{1 t}=\beta_{1}+\varepsilon_{i}
$$

Where; $i=1,2, \ldots, N$

The $\varepsilon_{i}$ is a random error term with a mean value of zero and variance of $\sigma_{\varepsilon}^{2}$. Thus, re-writing equation (6) by incorporating equation (7), would result in equation (8) below:

$$
Y_{i t}=\beta_{1 i}+\beta_{2 i} X_{2 i t}+\beta_{3 i} X_{3 i t}+\pi_{i t}
$$

Where; $\pi_{i t}=\varepsilon_{i}+\mu_{i t}$

The $\pi_{i t}$ (composite error term) is made up of two components: $\varepsilon i$, which is the cross-section, or individualspecific error component, and $\mu_{i t}$, which is the combined time series and cross-section error component.

\section{Durbin-Wu-Hausman (DWH) specification test}

The Durbin-Wu-Hausman (DWH) specification test (also called the Hausman specification test) detects endogenous regressors (predictor variables) in a regression model. Endogenous variables have values that are determined by other variables in the system. Having endogenous regressors 
Table 1. Descriptive Statistic

\begin{tabular}{cccccccccc}
\hline & $\mathbf{N}$ & Range & Minimum & Maximum & \multicolumn{2}{c}{ Sum } & Mean & Std. Dev. & Variance \\
\hline Variables & Statistic & Statistics & Statistics & Statistic & Statistic & Statistic & Statistic & Statistic & Statistic \\
\hline ETR & 319 & .40 & .12 & .52 & 93.32 & .2895 & .00325 & .06705 & .004 \\
\hline FSIZE & 319 & 4.85 & 8.14 & 12.99 & 3482.3 & 10.111 & .04266 & .54149 & .642 \\
\hline LEV & 319 & .93 & .12 & 1.05 & 243.40 & .5278 & .01077 & .16845 & .042 \\
\hline ROA & 319 & .83 & .01 & .84 & 36.77 & .1083 & .00531 & .08223 & .015 \\
\hline CAPINT & 319 & .94 & .15 & 1.09 & 145.67 & .5115 & .01310 & .32167 & .047 \\
\hline INVINT & 319 & .51 & .21 & .72 & 46.21 & .1471 & .00765 & .20214 \\
\hline
\end{tabular}

Table 2. Correlation Matrix

\begin{tabular}{|c|c|c|c|c|c|c|}
\hline Variables & ETR & FSIZE & LEV & ROA & CAPINT & INVINT \\
\hline ETR & 1 & & & & & \\
\hline FSIZE & $.768 *$ & 1 & & & & \\
\hline LEV & -.006 & .106 & 1 & & & \\
\hline CAPINT & $-.118^{*}$ & $.320 * *$ & $-.288 * *$ & $-.133 *$ & 1 & \\
\hline INVINT & $.647 *$ & $-.301 * *$ & $.205 * *$ & .009 & $-.486 * *$ & 1 \\
\hline
\end{tabular}

* Significant at $0.05, *$ Significant at 0.01

KEY:

ETR Effective Tax Rate

FSIZE Firm size

LEV Firm leverage

ROA Return on Asset

CAPINT Capital intensity

INVINT Inventory intensity

in a model will cause ordinary least squares estimators to fail, as one of the assumptions of OLS is that there is no correlation between a predictor variable and the error term. Instrumental variables estimators can be used as an alternative in this case. However, before you can decide on the best regression method, you first have to figure out if your predictor variables are endogenous using the Hausman test. The Hausman test is also used to choose between the fixed-effects model or a randomeffects model. The null hypothesis $\left(\mathrm{H}_{0}\right)$ is that the preferred model is random effects while the alternate hypothesis $\left(\mathrm{H}_{\mathrm{I}}\right)$ is that the model is a fixed-effects.

$\mathrm{H}_{0}$ : random effect (random effect regression model is preferred)

vs.

$\mathrm{H}_{\mathrm{I}}$ : fixed effect (fixed effect regression model is preferred)

Essentially, the tests look to see if there is a correlation between the unique errors and the regressors in the model (Hausman, 1978). Interpreting the result from a Hausman test is fairly straightforward: if the p-value is small (less than 0.05), reject the null hypothesis. The problem comes with the fact that many versions of the test with the different hypotheses and possible conclusions exist. In fact, some of the available tests suggest opposite conclusions about the null hypothesis (Chmelarova, 2007).

\section{RESULTS AND DISCUSSIONS}

This section presents the descriptive statistics (mean, standard deviation, maximum, and minimum), correlation matrix between the variables across the panels and the time variants, variance inflation factor, pooled ordinary least square (POLS) model, random effect regression model, fixed effect regression model and finally the Hausman test result.

\section{Descriptive Statistics}

Table 1 presents the descriptive statistics of the investigated determinants of ETRs, it shows that the determinants of the mean value of ETR portray wide variations, and the standard deviations also varying widely. A critical examination of the descriptive statistics for the response and explanatory variables reveals several issues. The average effective tax return (ETR) is $28.95 \%$. The first measure of performance (FSIZE) shows that Nigerian companies have a very low performance. The very high ratio of FSIZE of $814 \%$ recorded may reflect the low performance. The average value for the firm's leverage (LEV) is $52.78 \%$. The mean value of return on Asset (ROA) of $10.83 \%$ as compared to $51.15 \%$ mean value of the Capital intensity (CAPINT) shows that capital intensity is highest that the firm's return on Assets while Inventory intensity (INVINT) is $17.41 \%$.

\section{Correlation Matrix}

Table 2 presents their Pearson correlation coefficient matrix of the corporate effective tax rate (ETR) and firm-level attribute. The result shows that most of the variables produce a weak positive and strong negative and positive correlation between the explanatory variables, some of whom are significant at both $1 \%$ and $5 \%$ significant. It can be observed that FSIZE and ETR are positively correlated with ( $r=0.768)$; It connotes that larger firm can pay more tax, this finding is consistent with the finding of Richardson et al. (2013), Desai and Dharmapala (2006), Desai and Dharmapala (2009), and Ribeiro (2015), but not in agreement with that of Richardson and Lanis (2007). It was also discovered that; ETR is directly correlated with LEV and FSIZE, evidencing a positive impact of leverage and firm size on the improvement of the effective tax rate (ETR). This finding agrees with that of Richardson and Lanis (2007), and Modigliani and Miller (1963). Return on asset (ROA) is directly correlated with effective tax return (ETR) $(r=$ 
Table 3. Variance Inflation Factor

\begin{tabular}{ccc}
\hline \multirow{2}{*}{ Variables } & \multicolumn{2}{c}{ Collinearity Statistics } \\
\cline { 2 - 3 } & Tolerance & VIF \\
\hline FSIZE & 0.813 & 1.229 \\
LEV & 0.859 & 1.165 \\
ROA & 0.968 & 1.033 \\
CAPINT & 0.659 & 1.517 \\
INVINT & 0.728 & 1.373 \\
\hline
\end{tabular}

0.105), firm size (FSIZE) $(r=0.052)$ and firm leverage (LEV) $(r=0.013)$ of the firm and are insignificant at the $1 \%$ and $5 \%$ significant level. This implies that return on asset is a source of tax shield which helps to increase effective tax return, firm size, and firm leverage. The finding is not consistent with Harris and Feeny (2003). The result also indicated CAPINT is negatively correlated with ETR $(r=-0.118)$, FSIZE $(r=$ -0.32), LEV ( $r=-0.288)$, ROA and $(r=-0.133)$ and were significant at the $1 \%$ and $5 \%$ levels.

\section{Variance Inflation Factor (VIF) of the Models}

The Variance Inflation Factor (VIF) result is a criterion used to test for the presence of Multicollinearity in the variables. Multicollinearity occurs if the VIF value is greater than 10 . The VIF value of each explanatory variable presented in Table 3 shows that all predictor variables have VIF values $<10$. Thus all the variables can be included in the subsequent analysis.

\section{Estimation of the Panel Data Regression Model}

The results of the Pooled Ordinary Least Square (OLS), Fixed Effects and the Random Effects estimation models for the panel data for each of the effective tax rates (ETR) performance measures and for the full sample of observations for the period 2012 to 2018 are displayed in Table 4 to Table 6.

\section{Pooled Ordinary Least Square (POLS) model}

The pooled ordinary least square (POLS) result presented in Table 4 shows that the total firm size (FSIZE) has a positive significant relationship with the market performance measure effective tax rates (ETR) with coefficient and $\mathrm{p}$-value $\left(\beta_{1}=\right.$ $0.14569395, P=0.0009128)$. Return on Asset (ROA) and inventory intensity (INVINT) $\quad\left(\beta_{3}=0.16688228, P=\right.$ 0.0011756) and $\quad\left(\beta_{5}=0.16204212, P=0.0057434\right)$ respectively, also had a positive and significant relationship with the performance measured by effective tax rates (ETR) as given by the pool ordinary least square (POLS) model at $1 \%$ and $5 \%$ significant level. Firm leverage (LEV) and Capital intensity (CAPINT) shows a non-significant negative relationship with the performance measure $\left(\beta_{2}=-0.01306612, P=\right.$ $0.5397128)$ and $\left(\beta_{4}=-0.01563760, P=0.434081\right)$ as given by the pooled OLS. The R square and adjusted R square is $\left(R^{2}=\right.$ $72.3 \%$ and adjusted $R^{2}=69.6 \%$ ), respectively, for the pooled ordinary least square. The result indicates that more than $72 \%$ of the variation in effective tax rates (ETR) has been explained by firm size, leverage, return on asset, capital intensity, and

Table 4. Pooled Ordinary Least Square (POLS) Model

\begin{tabular}{ccccc}
\hline Coefficients & Estimate & Std. Error & t-value & $\boldsymbol{P}_{\boldsymbol{r}}(>|\boldsymbol{t}|)$ \\
\hline (Intercept) & 0.19893015 & 0.05434423 & 3.6606 & 0.0002991 \\
FSIZE & 0.14569395 & 0.00551823 & 4.1258 & 0.0009124 \\
LEV & -0.01306612 & 0.02128109 & -0.6140 & 0.5397128 \\
ROA & 0.16688228 & 0.04066015 & 6.6449 & 0.0011756 \\
CAPINT & -0.01563760 & 0.01996325 & -0.7833 & 0.4340811 \\
INVINT & 0.16204212 & 0.03252378 & 3.9076 & 0.0057435 \\
\hline Total Sum of Square & 1.1706 & & & \\
Residual Sum of Square & 1.1296 & & & \\
+R-Square & 0.720541 & & & \\
Adj. R-Square & 0.69623 & & & \\
F-Statistic & 11.89894 & & & \\
P-value & 0.025607 & & & \\
\hline
\end{tabular}

One-way (individual) effect pooling Model, Balanced Panel: $\mathrm{n}=59, \mathrm{~T}=5, \mathrm{~N}=319$, minimum $=-0.165$, maximum $=0.126,1^{\text {st }}$ Quartile $=-0.0435$, median $=0.0014$ and $3^{\text {rd }}$ Quartile $=0.0501$

Table 5. Fixed Effects Model Regression Model

\begin{tabular}{ccccc}
\hline Coefficients & Estimate & Std. Error & t-value & $\boldsymbol{P}_{\boldsymbol{r}}(>|\boldsymbol{t}|)$ \\
\hline (Intercept) & 0.178435 & 0.076324 & 2.2175 & 0.0315 \\
FSIZE & 0.265934 & 0.0151796 & 3.1752 & 0.0011 \\
LEV & -0.0348513 & 0.0374036 & -0.9318 & 0.3524 \\
ROA & 0.7873270 & 0.0662445 & 3.1885 & 0.0023 \\
CAPINT & -0.0063103 & 0.0329235 & -0.1917 & 0.8482 \\
INVINT & 0.1865450 & 0.0739156 & 2.4700 & 0.0014 \\
\hline Total Sum of Square & 0.503 & & & \\
Residual Sum of Square & 0.49325 & & & \\
+R-Square & 0.731391 & & & \\
Adj. R-Square & 0.702184 & & & \\
F-Statistic & 12.913572 & & & \\
P-value & 0.047289 & & & \\
\hline
\end{tabular}

One-way (individual) effect within Model Balanced Panel: $\mathrm{n}=59, \mathrm{~T}=5, \mathrm{~N}=319$, minimum $=-0.112$, maximum $=0.144,1^{\text {st }}$ Quartile $=-0.0234$, median $=0.0000$ and $3^{\text {rd }}$ Quartile $=0.0289$ 
Table 6. Random Effect Regression Model

\begin{tabular}{|c|c|c|c|c|}
\hline Coefficients & Estimate & Std. Error & t-value & $P_{r}(>|t|)$ \\
\hline (Intercept) & 0.1894681 & 0.0811350 & 2.3352 & 0.02022 \\
\hline FSIZE & 0.1400574 & 0.0080684 & 3.1806 & 0.00856 \\
\hline LEV & -0.021964 & 0.0272755 & -0.8053 & 0.42132 \\
\hline ROA & 0.1747764 & 0.0502870 & 2.4870 & 0.00138 \\
\hline CAPINT & -0.009895 & 0.0240302 & -0.4118 & 0.68080 \\
\hline INVINT & 0.80041 & 0.0444915 & 2.79926 & 0.03711 \\
\hline Total Sum of Square & 0.62214 & & & \\
\hline Residual Sum of Square & 0.60763 & & & \\
\hline +R-Square & 0.82331 & & & \\
\hline Adj. R-Square & 0.75644 & & & \\
\hline F-Statistic & 8.37998 & & & \\
\hline P-value & 0.01558 & & & \\
\hline
\end{tabular}

One-way (individual) Random Effect Model (Swamy-Arora's transformation) Balanced Panel: $\mathrm{n}=59, \mathrm{~T}=5, \mathrm{~N}=319$, minimum =-0.139, maximum = $0.138,1^{\text {st }}$ Quartile $=-0.0491$, median $=0.0016$ and $3^{\text {rd }}$ Quartile $=0.0344$

inventory intensity, leaving the other percentage unexplained due to the presence of stochastic error term. The F-statistics and $\mathrm{p}$-value of $(F=11.89$ and $P-$ value $=0.0256)$ indicate that $F-$ statistics and $p-$ value are also satisfactory and significant enough at $5 \%$ level of significance for use in making a useful inference.

\section{Fixed effect regression model}

The fixed effect regression model result presented in Table 5 shows that the total firm size (FSIZE) has a positive significant relationship with the market performance measured by effective tax rates (ETR) with coefficient and pvalue $\left(\beta_{1}=0.265934, P=0.0011\right)$. It was also discovered that return on Asset (ROA) also has a direct significant relationship with corporate effective tax rates (ETR), the coefficient and pvalue is; $\left(\beta_{3}=0.787327, P=0.0023\right)$ and inventory intensity (INVINT) with coefficient and $\mathrm{p}$-value given as; $\left(\beta_{5}=\right.$ $0.18654, P=0.0014$ ) respectively, as given by the fixed effect regression model at $1 \%$ and $5 \%$ significant level. Firm leverage (LEV) and Capital intensity (CAPINT) shows a non-significant negative relationship with the effective tax return (ETR) $\left(\beta_{2}=\right.$ $-0.03485, P=0.3524)$ and $\left(\beta_{4}=-0.00631, P=0.8482\right)$ as given by the fixed effect regression model. The $\mathrm{R}$ square and adjusted $\mathrm{R}$ square is $\left(R^{2}=73.1 \%\right.$ and adjusted $\left.R^{2}=70.2 \%\right)$, respectively, for the fixed effect regression model. The result indicates that more than $73 \%$ of the variation in effective tax rates (ETR) has been explained by firm size, leverage, return on asset, capital intensity, and inventory intensity, leaving the other percentage unexplained due to the presence of stochastic error term. The F-statistics and p-value of ( $F=$ 12.91 and $P-$ value $=0.043)$ indicate that $F-$ statistics and $p$-value are also satisfactory and significant enough at $5 \%$ level of significance for use in making a useful inference.

\section{Random effect regression model}

The random effect regression model result is presented in Table 6, it shows that the total firm size (FSIZE), return on assets (ROA) and inventory intensity (INVINT) has a positive and significant relationship with the corporate effective tax rates (ETR), their coefficient and $\mathrm{p}$-value are given as; $\left(\beta_{1}=\right.$ $0.1400574, P=0.00856), \quad\left(\beta_{3}=0.1747764, P=0.00138\right)$ and $\left(\beta_{5}=0.1800410, P=0.03711\right)$ respectively, as given by the random effect regression model at $1 \%$ and $5 \%$ significant level. The result also indicated that; Firm leverage (LEV) and
Capital intensity (CAPINT) shows a non-significant negative relationship with effective tax rate (ETR) with $\left(\beta_{2}=\right.$ $-0.021964, P=0.42132)$ and $\left(\beta_{4}=-0.0009895, P=\right.$ $0.6808)$ as given by the random effect regression model. The $\mathrm{R}$ square and adjusted $\mathrm{R}$ square is $\left(R^{2}=\right.$ $82.3 \%$ and adjusted $R^{2}=75.6 \%$ ) , respectively, for the random effect regression model. The result indicates that more than $82 \%$ of the variation in effective tax rates (ETR) has been explained by firm size (FSIZE), leverage (LEV), return on asset (ROA), capital intensity (CAPINT) and inventory intensity (INVINT), leaving the other percentage unexplained due to the presence of stochastic error term. The F-statistics and p-value of $(F=8.37958$ and $P-$ value $=0.01558)$ indicate that $F-$ statistics and $p$-value are also satisfactory and significant enough at $5 \%$ level of significance for use in making useful for decision making.

\section{Durbin-Wu-Hausman (DWH) Specification Test Result}

The Durbin-Wu-Hausman (DWH) test was used to verify the preferred model between the fixed effect and random effect regression model. The null hypothesis $\left(\mathrm{H}_{0}\right)$ states that; the preferred model is random effects while the alternate hypothesis $\left(\mathrm{H}_{\mathrm{I}}\right)$ stated that; the preferred model as fixed effects. The Durbin-Wu-Hausman (DWH) Chi-square test result and p-value for pooled ordinary least square (POLS), fixed and random effect regression model are given; $\left(\chi^{2}=\right.$ $12.7326, P>0.4292),\left(\chi^{2}=15.654, P>0.6554\right)$ and $\left(\chi^{2}=\right.$ $17.5331, P>0.8753)$ respectively. It is observed that the three (3) $p$ - values are greater than 0.05 level of significance, this means that the null hypothesis which stated that; the preferred model is random effects cannot be rejected. This implies that the random effect model result is more efficient and consistent than that of the fixed effect models as seen in Table 7 . Hence, the results from the random effect model are preferred for the interpretation of the relationship between corporate effective tax rates (ETR) and firm size (FSIZE), firm leverage (LEV), return on Assets (ROA), Capital intensity (CAPINT) and Inventory intensity (INVINT). 
Table 7. Hausman test result for the three models

\begin{tabular}{ccc}
\hline Models & Hausman $\chi^{2}$ test & $\chi^{2} \mathbf{p}$-value \\
\hline Pool Ordinary Least Square & 12.7326 & 0.4292 \\
\hline Fixed Effect & 15.6540 & 0.6554 \\
\hline Random Effect & 175331 & 0.8753 \\
\hline
\end{tabular}

\section{CONCLUSION}

In this study, we investigated the influence of some corporate tax attributes in some selected large public listed firms in Nigeria with the avoidance of corporate effective tax rates (ETR). The study employed Pooled Ordinary Least Square (POLS), fixed effect and random effect regression model to ascertain the influence and level of relationship between corporate effective tax rates (ETR) and firm size (FSIZE), return on assets (ROA), inventory intensity (INVINT), firm leverage (LEV) and capital intensity (CAPINT).

The results of the analysis show that the preferred model is the random effect regression model based on the Durbin-WuHausman (DWH) test result of $(p-0.4292,0.6554$ and 0.8753$)$ which were insignificant at the $5 \%$ level of significance. The result of the regression test of panel data using the randomeffect model proves that the attributes of the firms, namely the firm size, return on assets, inventory intensity, firm leverage, and capital intensity. The negative relationship between the firm leverage (LEV) and capital intensity (CAPINT) on tax avoidance indicates that the higher the level of leverage of the firm and the capital base of the firm the smaller the value of effective tax rate (ETR), this implies that tax avoidance measures in the company increase. The results also prove that the total firm size (FSIZE), return on assets (ROA) and inventory intensity (INVINT) has a positive and significant relationship with the corporate effective tax rates (ETR) avoidance, this indicates that the greater the firm size, the higher their ETR value will be, which means that the firm reduces tax avoidance. On the effect of return on assets, it was discovered that; the higher the return on assets the higher the effective tax rate (ETR) indicating that the tax avoidance in the firm is reduced. While the higher the inventory intensity the higher the effective tax rate (ETR), which indicates the higher level of tax avoidance by the company.

The results of the study also prove that more than $82 \%$ of the variation in effective tax rates (ETR) has been explained by firm size (FSIZE), leverage (LEV), return on asset (ROA), capital intensity (CAPINT) and inventory intensity (INVINT), leaving the other percentage unexplained due to the presence of stochastic error term. Based on the findings of this study, it is suggested that; firm size, return on asset and inventory intensity are the major factors that influence corporate effective tax rate positively in Nigeria over the period of consideration.

\section{ACKNOWLEDGEMENTS}

The authors acknowledge the members of staff of the department of Statistics, faculty of Science, University of Abuja, Nigeria for their support and encouragement throughout the period of writing this work. Special appreciation to the Management of Nigeria Financial report for their contributions in data search.. The authors are equally grateful to prospective peer reviewers and editors.

\section{REFERENCES}

Adhikari, A., Derashid, C. and Zhang, H. (2006). Public Policy, Political Connections, and Effective Tax Rates: Longitudinal Evidence from Malaysia. Journal of Accounting and Public Policy, 25(5), 574-595. https://doi.org/10.1016/j.jaccpubpol.2006.07.001

Atta-Mills, J. (2002). Improving resources and Organisational Structure of Tax Administration. Presentation at the 3rd Regional Workshop on taxation.

Badarau-Semenescu, C. and Semenescu, A. (2010). Fiscal Policy and the Cost of External Finance to Firms: Microeconomic and Macroeconomic Implications. Emerging Markets Finance \& Trade, 46(1), 36-50. https://doi.org/10.2753/REE1540-496X4603S103

Calvé Pérez, J. I., Labatut Serer, G. and Molina Llopis, R. (2005). Variables económico-financieras que inciden sobre la presión fiscal soportada por lasempresas de reducida dimensión: Efectos de la reforma fiscal de 1995 en las empresas de la comunidad valenciana. Spanish Journal of Finance and Accounting, 34(127), 875-897. https://doi.org/10.1080/02102412.2005.10779565

Chen Chen, S., Chen, X., Cheng, Q. and Shevlin, T. J. (2010). Are Family Firms More Tax Aggressive Than NonFamilyFirms? Journal of Financial Economics, 95(1), 41-61. https://doi.org/10.1016/j.jfineco.2009.02.003

Chmelarova, V. (2007). The Hausman test, and Some Alternatives, with Heteroskedastic Data.

Derashid, C. and Zhang, H. (2003). Effective Tax Rates and the 'Industrial Policy' Hypothesis: Evidence from Malaysia. Journal of International Accounting, Auditing and Taxation, 12(1), 45-62. https://doi.org/10.1016/S1061-9518(03) 00003-X

Desai, M. A. and Dharmapala, D. (2009). Corporate Tax Avoidance and Firm Value. Review of Economics and Statistics, 91(3), 537-546. https://doi.org/10.1162/ rest.91.3.537

Desai, M. and Dharmapala, D. (2006). Corporate Tax Avoidance and High-Powered Incentives. Journal of Financial Economics, $\quad 79(1), \quad$ 145-179. https://doi.org/10.1016/ j.jfineco.2005.02.002

Feeny, S., Gillman, M. and Harris, M. N. (2006). Econometric Accounting of the Australian Corporate Tax Rates: A Firm Panel Example. Accounting Research Journal, 19(1), 64-73. 
Fernández-Rodríguez, E. (2004). Los factores condicionantes de la presión fiscal empresarial española a partir de la información contable: Especial mención a las decisions financieras. Spanish Journal of Finance and Accounting, 33(120), 125-159. https://doi.org/10.1080/02102412.2004. 10779516

Fernández-Rodríguez, E. and Martínez-Arias, A. (2011). Determinants of Effective Tax Rate: Evidence for the USA and the EU. Intertax, 39(8-9), 381-395.

Fernández-Rodríguez, E. and Martínez-Arias, A. (2014). Determinants of Effective Tax Rate in the BRIC Countries. Emerging Markets Finance and Trade, 50(3), 214-228. https://doi.org/10.2753/REE1540-496X5003S313

Gujarati, D. N. (2003). Basic Econometric (4th Ed.), New York: McGraw-Hill Inc.

Gupta, S. and Newberry, K. (1997). Determinants of the variability of corporate effective tax rates: evidence from longitudinal data. Journal of Accounting and Public Policy, 16(1), 1-34. https://doi.org/10.1016/S0278-4254(96)00055 $-5$

Harris, M. and Feeny, S. (1999). The Determinants of Corporate Effective Tax Rates: Evidence from Australia. Working Paper no. 21/99, Melbourne Institute of Applied Economic and Social Research, University of Melbourne, Melbourne, Victoria, Australia. Habit Persistence in Effective Tax Rates. Applied Economics, 35(8), 951-958. https://doi.org/10.1080/0003684032000050577

Harris, M. N. and Feeny, S. (2003). Habit persistence in effective tax rates. Applied Economics, 35(8), 951-958. https://doi.org/10.1080/0003684032000050577

Hausman, J. (1978). Specification Tests in Econometrics. Econometrica, 46(6), 1251-1271. https://doi.org/10.2307/ 1913827

Janssen, B. (2005). Corporate Effective Tax Rates in the Netherlands. De Economist, 153(1), 47-66. https://doi.org/10.1007/s10645-004-7127-y

Kim, K. A. and Limpaphayom, P. (1998). Taxes and Firm Size in Pacific-Basin Emerging Economies. Journal of International Accounting, Auditing and Taxation, 7(1), 4768. https://doi.org/10.1016/S1061-9518(98)90005-2

Liu, X. and Cao, S. (2007). Determinants of Corporate Effective Tax Rates: Evidence from Listed Companies in China. Chinese Economy, 40(6), 49-67. https://doi.org/10.2753/ CES1097-1475400603

Modigliani, F. and Miller, M. (1963). Taxes and the Cost of Capital: A Correction. American Economic Review, 53(3), 433.

Noor, R. M., Fadzillah, N. S. M. and Mastuki, N. (2010). Corporate Tax Planning: A Study on Corporate Effective Tax Rates of Malaysian Listed Companies. International Journal of Trade, Economics, and Finance, 1(2), 189-193. https://doi.org/10.7763/IJTEF.2010.V1.34
Oloyede, I. O. (2010). Repositioning the Nigeria's Tax System: Suggestion Policy Measures. Available at: https://www.googlebooks.com

Omer, T. C., Molloy, K. and Ziebart, D. (1993). An Investigation of the Firm Size Effective Tax Rate Relation in the 1980s. Journal of Accounting, Auditing, and Finance 8(2), 167-182. https://doi.org/10.1177/0148558X9300800206

Pesaran, M., Shin, Y. and Smith, R. J. (2000). Structural Analysis of Vector Error Correction A model with Exogenous Variables. Journal of Econometrics, 97(2), 293343. https://doi.org/10.1016/S0304-4076(99)00073-1

Plesko, G. A. (2003). An Evaluation of Alternative Measures of Corporate Tax Rates. Journal of Accounting and Economics, 35(2), 201-226. https://doi.org/10.1016/S0165-4101(03) 00019-3

Porcano, T. M. (1986). Corporate Tax Rates: Progressive, Proportional, or Regressive. Journal of the American Taxation Association, 7(2), 17-31.

Ribeiro, A. M. (2015). The determinants of effective tax rates: firm characteristics and corporate governance (Masters Thesis in Finance and Taxation), Universidad Do Porto.

Richardson, G. and Lanis, R. (2007). Determinants of the variability in corporate effective tax rates and tax reform: Evidence from Australia. Journal of Accounting and Public Policy, 26, 689-704. https://doi.org/10.1016/j.jaccpubpol. 2007.10.003

Richardson, G., Taylor, G. and Lanis, R. (2013). The impact of board director oversight characteristics on corporate tax aggressiveness: An empirical analysis. Journal of Accounting and Public Policy, 32(3), 68-88.

Salaudeen, Y. M. (2017). Corporate Effective Tax Rates in the Financial Services Sector: Evidence from Nigeria. International Journal of Accounting and Taxation, 5(1), 6888. https://doi.org/10.15640/ijat.v5n1a6

Stickney, C. P. and McGee, V. E. (1982). Effective Corporate Tax Rates: The Effect of Size, Capital Intensity, Leverage, and Other Factors. Journal of Accounting and Public Policy, 1(2), 125-152. https://doi.org/10.1016/S0278-4254(82) 80004-5

Teidi (2003). Federalism and Intergovernmental Fiscal Relations in Nigeria, Ibadan: Spectrum Books Ltd.

Wang, S. (1991). The Relation Between Firm Size and Effective Tax Rates: A Test of Firms' Political Success. Accounting Review, 66(1), 158-169.

Wilkinson, B., Cahan, S. and Jones, G. (2001). Strategies and Dividend Imputation: The Effect of Foreign and Domestic Ownership on Average Effective Tax Rate. Journal of International Accounting, Auditing and Taxation, 10(2), 157175. https://doi.org/10.1016/S1061-9518(01)00042-8

Wooldridge, J. M. (2010). Econometric Analysis of Cross Section and Panel Data. Cambridge, MA: MIT Press.

Zimmerman, J. (1983). Tax and firm size. Journal of Accounting and Economics, 5(2), 119-149. https://doi.org/10.1016/ 0165-4101(83)90008-3 